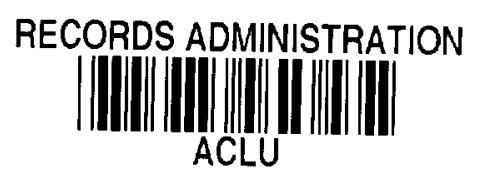

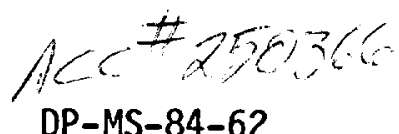

\title{
LEACHING OF DEVITRIFIED GLASS CONTAINING SIMULATED SRP NUCLEAR WASTE
}

by

Carol M. Jantzen and Dennis F. Bickford

E. I. du Pont de Nemours \& Company Savannah River Laboratory Aiken, South Carolina 29808

\section{SRL \\ RECORD COPY}

A paper for presentation at the

1984 Annual Meeting of the Materials Research Society

Boston, Massachusetts

November 26-30, 1984

and for publication in the proceedings

This paper was prepared in connection with work done under Contract No. DE-AC09-76SR00001 with the U.S. Department of Energy. By acceptance of this paper, the publisher and/or recipient acknowledges the U.S. Government's right to retain a nonexclusive, royalty-free license in and to any copyright covering this paper, along with the right to reproduce and to authorize others to reproduce all or part of the copyrighted paper. 
This document was prepared in conjunction with work accomplished under Contract No.

DE-AC09-76SR00001 with the U.S. Department of Energy.

\section{DISCLAIMER}

This report was prepared as an account of work sponsored by an agency of the United States Government. Neither the United States Government nor any agency thereof, nor any of their employees, makes any warranty, express or implied, or assumes any legal liability or responsibility for the accuracy, completeness, or usefulness of any information, apparatus, product or process disclosed, or represents that its use would not infringe privately owned rights. Reference herein to any specific commercial product, process or service by trade name, trademark, manufacturer, or otherwise does not necessarily constitute or imply its endorsement, recommendation, or favoring by the United States Government or any agency

thereof. The views and opinions of authors expressed herein do not necessarily state or reflect those of the United States Government or any agency thereof.

This report has been reproduced directly from the best available copy.

Available for sale to the public, in paper, from: U.S. Department of Commerce, National Technical Information Service, 5285 Port Royal Road, Springfield, VA 22161, phone: (800)

553-6847, fax: (703) 605-6900, email: orders@ntis.fedworld.gov online ordering: http://www.ntis.gov/ordering.htm

Available electronically at http://www.doe.gov/bridge

Available for a processing fee to U.S. Department of Energy and its contractors, in paper, from: U.S. Department of Energy, Office of Scientific and Technical Information, P.O. Box 62, Oak Ridge, TN 37831-0062, phone: (865 ) 576-8401, fax: (865) 576-5728, email: reports@ adonis.osti.gov 
CAROL $\cdot M$. JANTZEN AND DENNIS F. BICKFORD

E. I. du Pont de Nemours and Company, Savannah River Laboratory

Aiken, South Carolina 29808

\section{ABSTRACT}

Time-temperature-transformation curves have been determined for SRL-165 and SRL-131 waste glasses for all potential waste compositions. SRL-165 glasses, which contain less alkali, exhibit less complex devitrification and higher overall durability than SRL-131 waste glasses. Devitrification was found to have less effect on the durability of waste glasses than changes in composition. Non-uniform dissolution at the glass leached layer interface is observed. However, leached layers formed after 28 days shield the crystal interfaces from further dissolution.

\section{INTRODUCTION}

Devitrification (i.e. crystallization) is an important consideration in the processing and performance of nuclear waste glass. Time-temperaturetransformation (TTT) diagrams for various waste glass compositions have been developed to determine the effect of composition on devitrification. The crystallization behavior at high temperature is important during melter idling. Behavior at moderate temperature and time is important in potential accident/transportation scenarios. Behavior at low temperatures and long times is important for glass storage under repository conditions. Programmed cooling through the entire temperature range comparable to measured canister centerline cooling rates can establish glass crystallization behavior under worst case cooling conditions.

Waste glass durability as a function of devitrification is evaluated by comparative leach testing of both quenched and devitrified glasses. Interpretation of the mechanisms involved depend on microstructural and microchemical surface analyses coupled with leachate analyses.

In this study, the effects of glass composition on divitrification have been examined for simulated SRP waste glass formulations. The TTT curves, the effects of composition on devitrification, and the relative leachability of waste glass as a function of devitrified phase development are discussed. In particular, since devitrification can create additional grain boundaries which have been suggested to cause preferential dissolution and increased leachability $[1,2]$, the effects of the additional boundaries on release rates were determined.

\section{EXPERIMENTAL}

Glasses based on both SRL-131 frit and SRL-165 frit were made with fully simulated waste $[3,4]$. These glasses represent all potential waste compositions [5]. The glasses were melted under a controlled atmosphere to simulate normal melter operation, and subsequently heat treated to induce devitrification. The final redox of the glass was experimentally measured and the corresponding oxygen fugacity was $10^{-5}$ to $10^{-7}$ atmospheres depending on temperature. Samples were devitrified isothermally for various times, while other samples were devitrified during furnace cycles programed to simulate canister centerline cooling. The glasses were quantitatively analyzed by magnetic susceptibility $[3,6]$, quantitative x-ray diffraction [6], and scanning electron microscopy [4]. Phase identification was determined by optical microscopy, x-ray diffraction, quantitative scanning electron microscopy, and electron microprobe. 
Durability of quenched and devitrified glasses of each composition were compared by means of a 24 hour static leach test developed by Corning Glass Works (CGW) for crushed glass and by a 28 day static scoping leach test suggested by the Materials Characterization Center (MCC) [7] for monoliths of glass. The CGW test allows a larger volume of the sample to be analyzed, and is believed to provide more representative results. This is especially important since the devitrification can be inhomogeneous over a small volume of the sample. Hence, the MCC test required replicate analyses.

For the 24 hour CGW test, ten grams of devitrified glass was ground and sieved between 100 and 200 mesh. Two grams of sample were placed in $100 \mathrm{~mL}$ of deionized water in a polyethylene bottle and leached for 24 hours in a convection oven at $80^{\circ} \mathrm{C}$. The $\mathrm{pH}$ was measured and an aliquot of the leachate was analyzed by inductively coupled plasma (ICP) for B, Si, and Na. The effective SA/V is approximately $4.3 \mathrm{~cm}^{-1}$. For the 28 day MCC test, the samples were core drilled and not polished. Samples of about 1-1.5 grams were placed in deionized water in Teflon ${ }^{\circledR}$ vessels and leached for 28 days in a convection oven at $90^{\circ} \mathrm{C} \mathrm{[7]}$. The $\mathrm{pH}$ was measured and an aliquot of the leachate was analyzed by ICP.

The leached gel layers which formed on the flat surfaces of the monolithic samples were partially removed with adhesive. The glass microstructure at the glass/leached layer interface could then be examined by scanning electron microscopy. The unstripped portion of the sample allowed direct comparison of the morphology of the gel/solution interface by SEM. Examination of the bottom side of the adhesive provided a comparison with the gel microstructure at the glass/leached layer interface. Comparison of the glass microstructure and the gel microstructure at the glass/gel reaction front provided comparative data for examining nonuniform dissolution. Energy dispersive $x$-ray andysis of the elements concentrated in the gel at the reaction zone provided microchemical data.

\section{TIME-TEMPERATURE-TRANSFORMATION CURVES}

Quantitative $x$-ray diffraction analyses of SRL-165 waste glasses were verified by SEM and optical microscopy. Spinel, nominally $\mathrm{NiFe}_{2} \mathrm{O}_{4}$, is the devitrified phase at temperatures between 750 and $1025^{\circ} \mathrm{C}$, (Figure 1). The sodium iron silicate, acmite $\left(\mathrm{NaFeSi}_{2} \mathrm{O}_{6}\right)$, forms at lower temperatures and the maximum rate of devitrification determined from fractional ingrowth curves occurs at $700^{\circ} \mathrm{C}$.

SRL-131 glasses also form spinel in the high temperature range, e.g. 900 to $1050^{\circ} \mathrm{C}$. However, three alkali silicate phases ( $\mathrm{NaFeSi}_{2} \mathrm{O}_{6}$, $\mathrm{NaAlSiO}_{4}$, and $\mathrm{Li}_{2} \mathrm{SiO}_{3}$ ) form over both the higher and lower temperature range, e.g. between 500 and $950^{\circ} \mathrm{C}$ (Figure 2). A correlation of the temperature of crystallization of alkali silicate phases, e.g. $\mathrm{Li}_{2} \mathrm{SiO}_{3}$ and $\mathrm{NaAlSiO}_{4}$, with increasing $\left(\mathrm{Li}_{2} \mathrm{O}+\mathrm{Na}_{2} \mathrm{O} / \mathrm{SiO}_{2}+\mathrm{Al}_{2} \mathrm{O}_{3}\right)$ ratio was observed for SRL-131 waste glasses. The maximum rate of devitrification determined from fractional ingrowth curves occurs at $600^{\circ} \mathrm{C}$.

Spinel heterogenously crystallizes on $\mathrm{RuO}_{2}$ at high temperatures and short times ( $1-3$ hours) thereby influencing optimal melter idling conditions [4]. If the liquidus temperature is taken as the highest temperature of crystallization of spinel and the crystallization boundaries contoured represent $1-2$ percent crystallinity $[3,5,6]$, these values are accurate to within $\pm 50^{\circ} \mathrm{C}$. The six liquidus temperatures represented in Figures 1 and 2 are directly proportional to the $\mathrm{Fe}_{2} \mathrm{O}_{3} / \mathrm{SiO}_{2}$ content of the glass in mole percent. This ratio may therefore be used to determine safe melter idling conditions as a function of waste composition. 
ine canister cencerline cooling curves can be superimposed on the timetemperature-transformation curves. For each waste glass composition, the cooling curve crosses the noses of the C-shaped transformation curves at less than 24 hours [4]. Simulated centerline cooling of SRL glasses represents worst case crystallization of the glass during canister cooling. The data from duplicate experiments is given in Table I.

TABLE I

Volume Percent Devitrification of Simulated Centerline Cooled Glasses* Determined by Quantative X-ray Diffraction

\begin{tabular}{|c|c|c|c|}
\hline & $\begin{array}{l}\mathrm{High} \\
\mathrm{Al} \\
\end{array}$ & Composite & $\begin{array}{l}\mathrm{High} \\
\mathrm{Fe} \\
\end{array}$ \\
\hline SRL 165 & 5 spinel & $\begin{array}{l}5-8 \text { spinel } \\
10-20 \text { acmite }\end{array}$ & $\begin{array}{l}8-12 \text { spinel } \\
18 \text { acmite }\end{array}$ \\
\hline SRL 131 & $35-40$ nephel ine & $\begin{array}{l}6 \text { spinel } \\
4 \text { nephel ine } \\
13 \text { acmite }\end{array}$ & $\begin{array}{l}10 \text { spinel } \\
14-16 \text { nephel ine }\end{array}$ \\
\hline
\end{tabular}

* error $+2 \%$ spinel, $\pm 5 \%$ acmite, $\pm 10 \%$ nepheline; all data confirmed by optica $\bar{T}$ microscopy and scarıning êlectron microscopy.

\section{RELATIVE DURABILITY OF DEVITRIFIED AND QUENCHED SRL WASTE GLASSES}

\section{Quantitative Durability: CGW Leach Tests}

The CGW leach test of powered devitrified glass was used for the determination of differential leaching as a function of phase development. Values of $\mathrm{pH}, \mathrm{Si}, \mathrm{Na}$, and $\mathrm{B}$ were contoured on the TTT diagrams but consistent trends were only observed for the release of the glass matrix element boron (Figures 1 and 2). Since boron is the most leachable species in defense waste glass [8], monitoring this element evaluates worst case leachability for divitrified glasses. The poor correlation of phase development with $\mathrm{Si}$ and $\mathrm{Na}$ may be due to their dual role in both the glass matrix and in the crystallization of acmite. The poor correlation with $\mathrm{pH}$ was due to the small range of values observed.

The boron release (in ppm) into solution from the quenched glasses is represented by the data points at $400^{\circ} \mathrm{C}$ and zero annealing time in Figures 1 and 2. The shaded region corresponds to any devitrified samples releasing more than twice the boron of the as-quenched sample for that composition. For example, the as-quenched sample of SRL-165 high alumina waste glass releases $1 \mathrm{ppm}$ boron to the leachate during the CGW test. The shaded region on the corresponding TTT diagram, therefore, represents all devitrified samples releasing 2 or more ppm boron to the leachant.

A comparison of the boron release values for the as-quenched SRL-165 waste glasses shows a variation from 1 to $3 \mathrm{ppm}$, a factor of $3 x$. Likewise, the variation for the SRL-131 based waste glasses show a variation from 4 to $20 \mathrm{ppm}$ boron, a factor of $5 x$. The effects of devitrification on the durability of the SRL-165 and SRL-131 waste glasses, therefore, demonstrates that devitrification has less effect than compositional changes. 

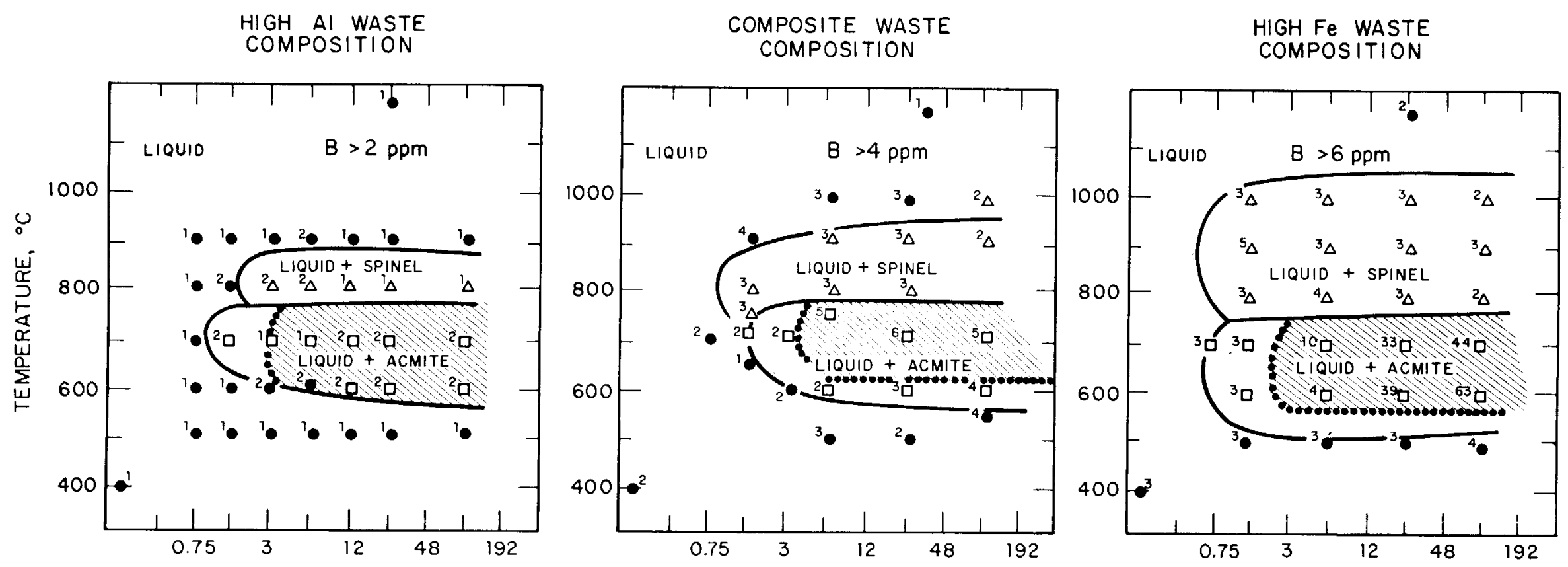

ISOTHERMAL ANNEALING TIME, hours

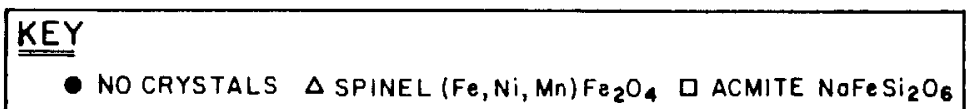

FIGURE 1. Time-temperature-transformation diagrains for SRL-165 waste glasses. Shaded area represents devitrified glasses which cause boron release rates in deionized water greater than twice the as-quenched boron release rate at zero time. 

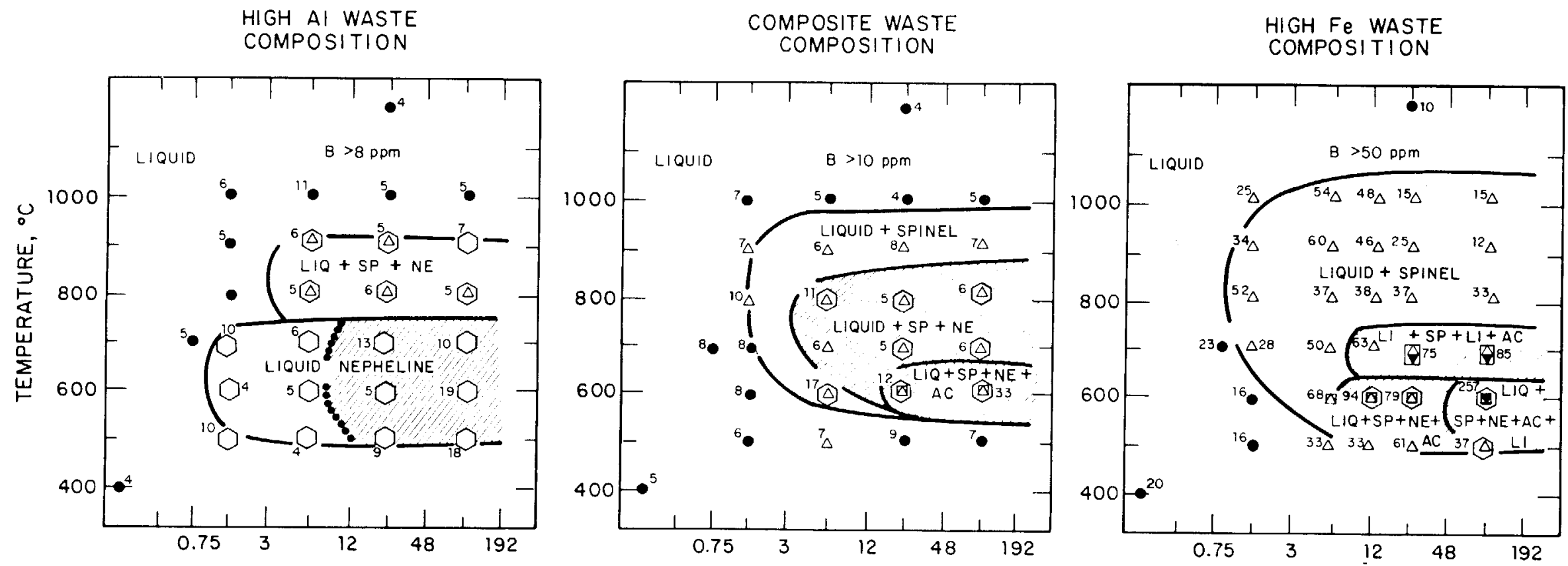

ISOTHERMAL ANNEALING TIME, hours

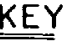

- NO CRYSTALS $\triangle$ SPINEL $(\mathrm{Fe}, \mathrm{Ni}, \mathrm{Mn}) \mathrm{Fe}_{2} \mathrm{O}_{4}$ व ACMITE NaFeSi $\mathrm{O}_{6} \bigcirc$ NePHELINE NaAlSiO

FIGURE 2. Time-temperature-transformation diagrams for SRL-131 waste glasses. Shaded area represents devitrified glasses which cause boron release rates in deionized water greater than twice the as-quenched boron release rate at zero time. 
Crystallization of spinel does not affect glass durability. Crystallization of alkali silicate phases correlates with the time-temperature regions of increased leachability. SRL-131 waste glasses are less durable than SRL-165 waste glasses in the as-quenched state (Figures 1 and 2) even when normalized to the differing amounts of boron in the parent glass (Table II). The devitrification of three different alkali silicate phases in SRL-131 glasses causes additional loss of durability.

TABLE II

Relative Durability for Quenched and

Devitrified SRL Waste Glasses

\begin{tabular}{lcc} 
& Baron Release $(P P M)^{*}$ & \\
\cline { 2 - 3 } Waste Glass & Quenched & $\begin{array}{c}\text { Devitrified at } \\
700^{\circ} \mathrm{C}>24 \text { hours }\end{array}$ \\
\cline { 2 - 3 } SRL-165 High A1 & 1 & $1-2$ \\
SRL-165 Composite & 2 & $5-6$ \\
SRL-165 High Fe & 3 & $33-44$ \\
& & Devitrified at \\
& & $600^{\circ} \mathrm{C}>24$ hours \\
SRL-165 High Al & 3 & $3-13$ \\
SRL-131 Composite & 3 & $9-22$ \\
SRL-131 High Fe & 17 & $18-65$
\end{tabular}

* Normalized to Wt $\%$ B in the different glasses

The maximum rate of devitrification occurs at $700^{\circ} \mathrm{C}$ for $S R L-165$ glasses and at $600^{\circ} \mathrm{C}$ for $\mathrm{SRL}-131 \mathrm{~g} 1$ asses. Release rates corresponding to a transportation/fire accident scenario, e.g. $790^{\circ} \mathrm{C}$ for 30 minutes, would be the same as the as-quenched values shown in Figures 1 and 2 since these conditions are coincident with the region where no devitrification occurs. The values shown can also be applied to worst case conditions of canister heating in the repository environment.

The high iron TTT diagrams represent worst case boron releases to the solution because microcracking is induced during the quenching from the isothermal annealing temperature. The boron release rates directly correlate with the volume percent acmite present. One potential explanation of this data could be thermal expansion mismatch caused by the growth of very large acmite crystals in these iron rich compositions. Subsequent experiments which slowly cooled the isothermally annealed samples, devitrified to the same extent but had leach rates comparable to non-devitrified samples of the same composition. Thus, fresh waste glass will not experience microcracking, due to the low volume percentage acmite and the slow cooling in the canister region of maximum devitrification.

SRL-165 and SRL-131 waste glasses devitrified during cooling simulating canister centerline temperatures yielded 23-25 volume percent crystallization. Only spinel and acmite crystallized in SRL-165 glasses while spinel, acmite, and nepheline crystallized in SRL-131 glasses. For SRL-165 glasses, this only increased the boron release by $2-3 x$ relative to the boron release of the nondevitrified, (i.e. quenched) glass. For SRL-131 glasses, the more complex devitrification of the additional alkali silicate phase, nepheline, caused a $5 X$ increase in the boron release relative to a non-devitrified glass of the same composition. 
Quantitative Durability: MCC-1 Leach Tests

Monolithic samples of devitrified glass are difficult to obtain due to sample cracking and crystal plucking during preparation. Since the monolith surface is representative of only a small volume of the sample, the MCC-1 test is more sensitive to sample inhomogeneities, e.g. non-uniform devitrification. Samples were, therefore, run in triplicate or quadruplicate.

The results of the static MCC-1 leach test in deionized water for 28 days demonstrate that the non-devitrified samples give reproducible boron releases but the devitrified samples do not (Table III). Variations of up to $2 X$ can be observed for the boron releases of devitrified samples.

\begin{tabular}{|c|c|c|c|c|c|}
\hline & Comparative & $\begin{array}{c}\text { TABLE III } \\
\text { CC-1 Leach Rates }\end{array}$ & or SRL & Gla & \\
\hline Glass & Condition & Volume Percent & Leach & Rates (NL & $\left.i, \mathrm{~g} / \mathrm{m}^{2}\right)$ \\
\hline Composition & Of Glass & Crystals & Boron & Silicon & Lithium \\
\hline $165 \mathrm{High}$ & Quenched & None & 8.39 & 7.81 & 9.36 \\
\hline Alumina & & & 9.06 & $\begin{array}{l}7.22 \\
9.78\end{array}$ & 8.56 \\
\hline & & & 8.16 & 8.61 & 10.32 \\
\hline & Centerline & & & & \\
\hline & Cooled & 8 Spinel & 11.46 & 8.41 & 10.59 \\
\hline & & & 16.03 & 11.11 & 19.51 \\
\hline & & & 25.17 & 24.25 & 37.86 \\
\hline & & & 27.12 & 24.45 & 38.29 \\
\hline 165 Composite & Quenched & None & 15.30 & 14.23 & 17.21 \\
\hline & & & 9.86 & 10.07 & 13.73 \\
\hline & Centerl ine & 5 Spinel & 15.34 & 10.32 & 18.16 \\
\hline & Cooled & 20 Acmite & 24.37 & 12.33 & 17.96 \\
\hline & & & 15.23 & 14.05 & 18.01 \\
\hline
\end{tabular}

Comparing the MCC-1 leach data for SRL-165 glasses in the quenched and devitrified states shows that no more than a factor of $1-3 x$ release of boron or silicon occurs due to devitrification. Leach rates for the more mobile alkali element lithium indicate no more than a factor of $4 x$ increase. Comparative durability of quenched and devitrified glass by $\mathrm{MCC}-1$ procedures confirms the results of the 24-hour CGW leach test.

\section{Validation of CGW Leach Test Results}

Comparison of leach data using the CGW method and the MCC-1 test method is given in Table IV. The data for $S i$ and $B$ release were compared for samples in the as-quenched, canister centerline cooled, and devitrified states. The leach rates were compared in units of $\mathrm{g} / \mathrm{m}^{2}$-day. Both tests showed that leach rates of the as-quenched and the centerline cooled glasses were similar, while extreme devitrification increased the leach rate of $5 i$ and $B$ by only a factor of 2 to 3 times (Table IV). The MCC-l leach test is more sensitive to small percentages of devitrification such as observed in the centerline cooled samples, but is more subject to error due to inhomogeneous devitrification. For rapid determination of the effects of devitrification, the CGW 24-hour test provides an accurate determination of leach rate enhancement. 
TABLE IV

Comparative Leach Rates for SRL -165 Composite Glass

\begin{tabular}{|c|c|c|c|c|c|}
\hline \multirow[b]{2}{*}{ Condition } & \multirow{2}{*}{$\begin{array}{l}\text { Volume Percent } \\
\text { Crystallinity }\end{array}$} & \multicolumn{4}{|c|}{ Leach Rate $\left(\mathrm{g} / \mathrm{m}^{2}-\mathrm{d}\right)$} \\
\hline & & $M C C-1^{* \star}$ & $\mathrm{CGW}^{\star}$ & MCC-1 & CGW \\
\hline Quenched & 0 & 0.45 & 0.24 & 0.48 & 0.28 \\
\hline $\begin{array}{l}\text { Simulated Canister } \\
\text { Centerl ine Cooling }\end{array}$ & $\begin{array}{r}5 \text { Spinel } \\
20 \text { Acmite }\end{array}$ & 0.63 & 0.22 & 0.75 & 0.28 \\
\hline $\begin{array}{l}\text { Heat Treated } 24 \mathrm{hrs} \\
\text { at } 700^{\circ} \mathrm{C}\end{array}$ & 20 Acmite & 0.79 & 0.40 & 1.25 & 0.74 \\
\hline $\begin{array}{l}\text { * CGW is a } 24-\mathrm{Hr} \text { Test } \\
100 \text { and } 200 \text { mesh to } \\
\mathrm{cm}^{-1} \text {. }\end{array}$ & $\begin{array}{l}\text { of about } 10 \mathrm{~g} p \\
\text { about } 2 \mathrm{~g} \text { with }\end{array}$ & $\begin{array}{l}\text { waste } \\
\text { fective }\end{array}$ & $\begin{array}{l}\text { glass } \\
\text { SA/V } 0\end{array}$ & $\begin{array}{l}\text { sieved } \\
\text { f about }\end{array}$ & 4.3 \\
\hline $\begin{array}{l}\text { MCC }-1 \text { is a } 28 \text { day } \\
0.1 \mathrm{Cm}^{-1} .\end{array}$ & $t$ of about 1 & $t$ & lass & ith & \\
\hline
\end{tabular}

CHARACTERIZATION OF REACTIONS AT THE GLASS-LEACHED SURFACE LAYER INTERFACE

The morphology of corrosion at the glass-gel reaction zone, e.g. under the leached layer, can be examined when the leached layer is stripped off with adhesive. Examination of the glass gel reaction zone by scanning electron microscopy of the stripped glass surface and comparative microscopy of the leached layer adhering to the adhesive enabled the morphology of the dissolution to be studied. The morphology of the leached layer for quenched glasses was highly structured and the dissolution nonuniform (Figure 3 ). The glass-gel interface of the SRL-131 glasses were more nonuniform (Figure 4) than the SRL-165 glasses (Figure 3 ). The nonuniformity of the dissolution has been observed previously for monolithic waste glass samples with rough or scratched surface finishes $[9,10]$.

Examination of devitrified and leached glass surfaces (SRL-165 high alumina, centerline cooled) at the glass-gel interface indicated the same nonuniform dissolution of the glass matrix with some non-uniform dissolution at the crystal grain boundary (Figure 5). However, the non-uniform dissolution is not enhanced in the region around the crystal (Figure 5d) compared to the depth of dissolution along a surface scratch (Figure $5 \mathrm{c}$ ). It is, therefore, impossible to distinguish whether accelerated attack is the result of grain boundary* dissolution or localized surface damage at the glass/crystal boundary during sample preparation.

Scanning electron microscopy of the leached layer at the gel-solution interface, e.g. with the leached layer intact, shows that the leached layer covers or shields the grain boundaries from dissolution (Figures 5 a, and 5b). Examination of the gel layer at the glass gel interface demonstrates this as wel1. Holes are apparent in the stripped off leached layer where the crystals had higher relief, e.g. were more resistant to leaching than the surrounding glass matrix. Moreover, energy dispersive x-ray analysis of the elements concentrated in the gel at the reaction zone provides microchemical data suggesting that the gel layer is ion-selective [11] and may contribute to the non-uniformity of the dissolution.

* Grain boundary is used synonymously with crystal boundary. 

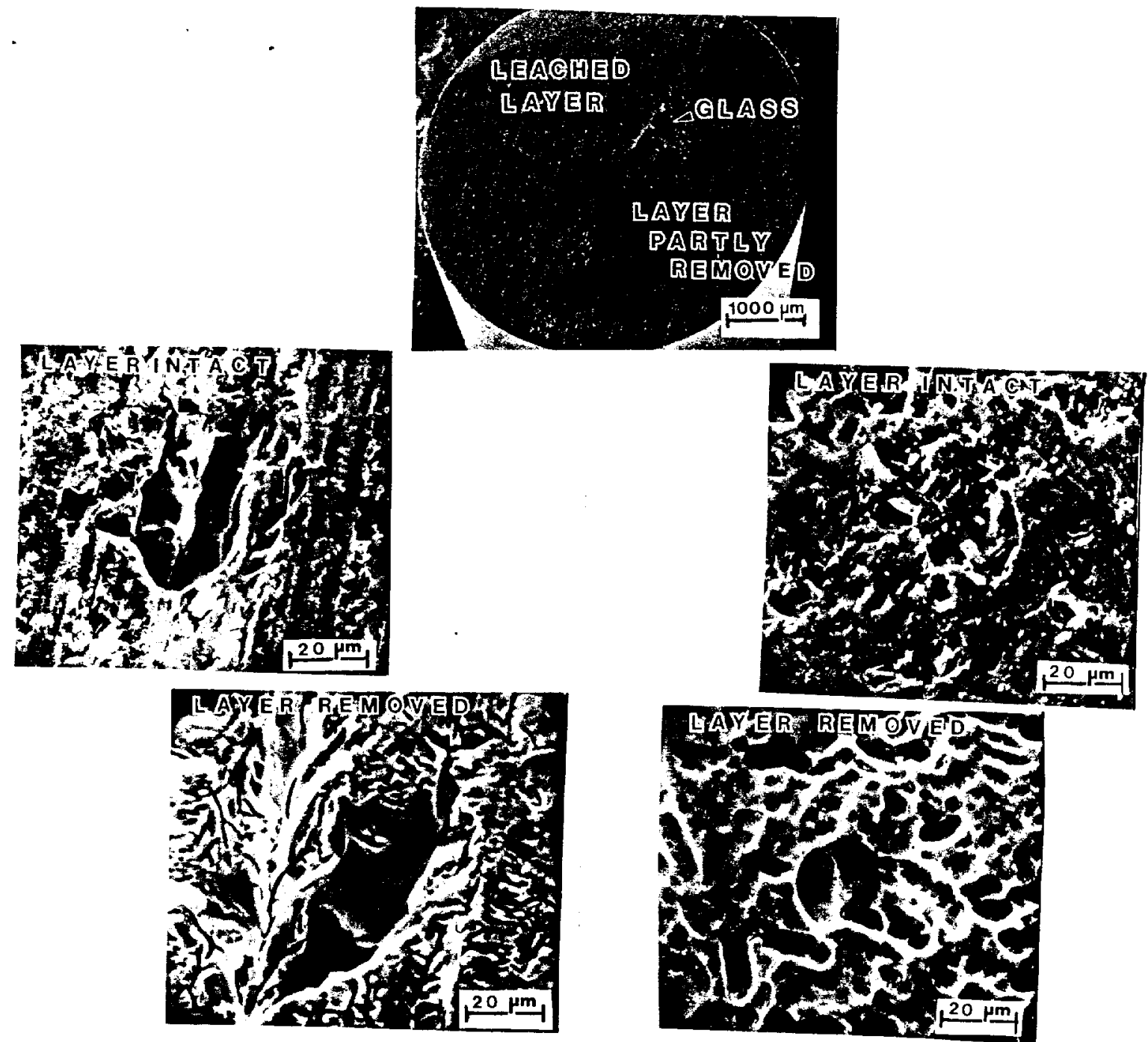

FIGURE 3. Surface morphology of quenched SRL-165 waste glasses (high alumina composition on left and composite composition on right) leached for 28 days in deionized water.

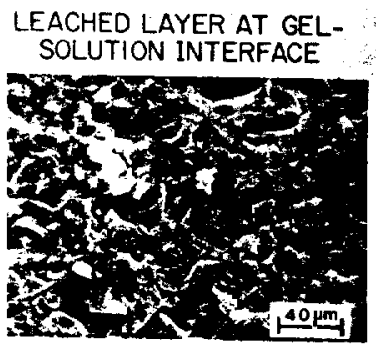

GEL LAYER AT GEL-GLASS INTERFACE
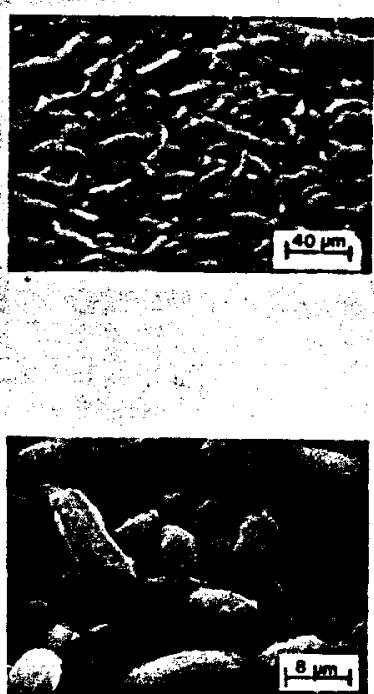

\section{GLASS AT GEL-GLASS} INTERFACE

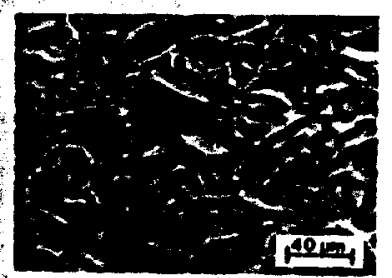

FIGURE 4. Surface morphology of quenched SRL-131 waste glasses (composite composition) leached for 28 days in deionized water. 

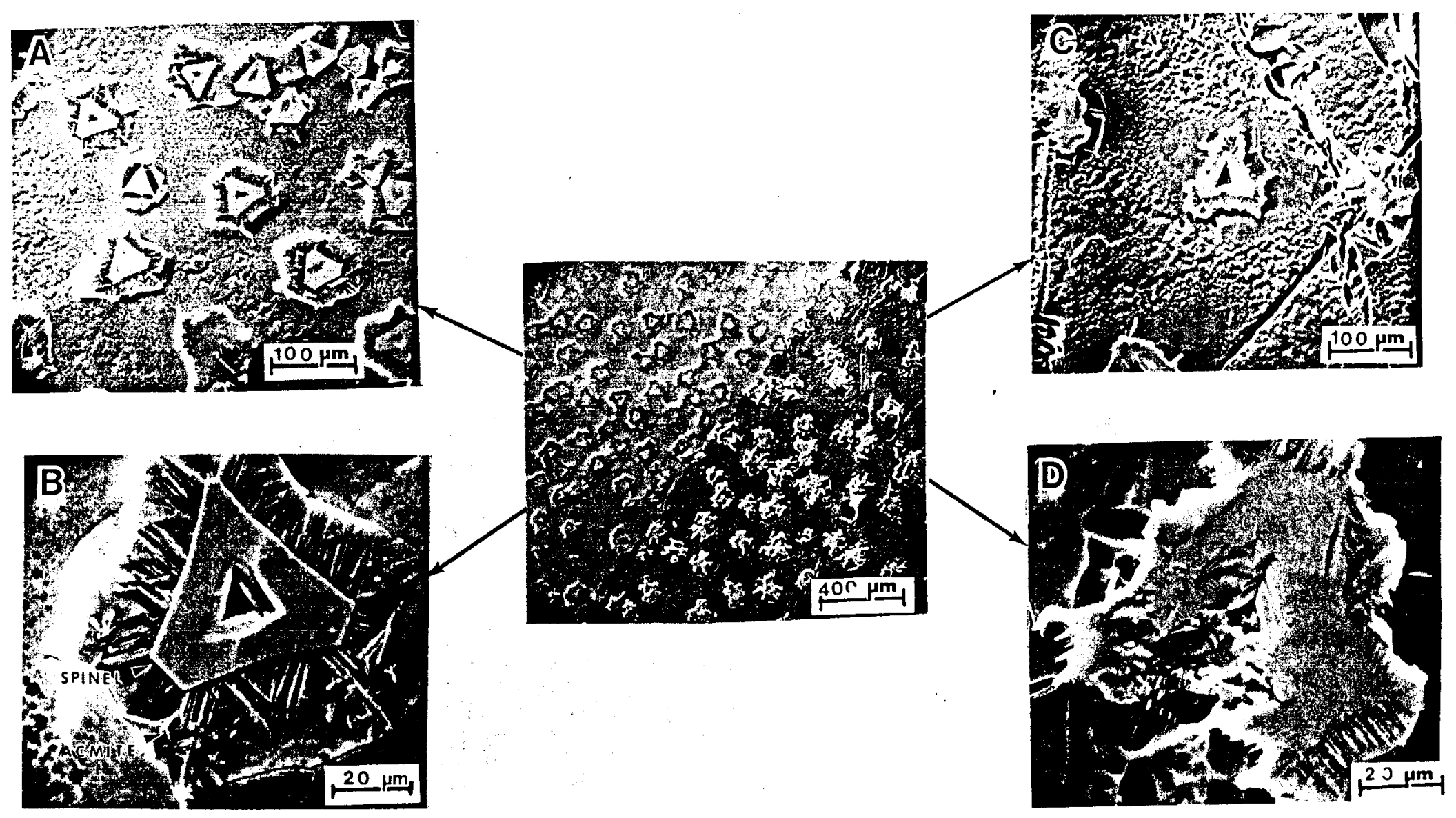

FIGURE 5. Surface morphology of devitrified centerline cooled SRL-165 high alumina waste glass leached for 28 days in deionized water. Note how the leached gel layer "shields" the grain boundary from dissolution (compare $5 b$ to $5 d$ ). 
Time-temperature-transformation diagrams for SRL-165 and SRL-131 waste glasses have been completed. The glasses are homogeneous when melted at $1150^{\circ} \mathrm{C}$ and do not crystallize when air quenched from this temperature, or when isothermally annealed below $500^{\circ} \mathrm{C}$. If isothermally treated, all SRL-165 waste glasses form spinel at high temperatures $\left(750-1000^{\circ} \mathrm{C}\right.$ ) and acmite in the lower temperature range $\left(600-800^{\circ} \mathrm{C}\right)$. The maximum rate of devitrification occurs at $700^{\circ} \mathrm{C}$. All SRL-131 waste glasses form spinel in the temperature range $900-1050^{\circ} \mathrm{C}$. Three alkali silicate phases form over both the higher and lower temperature range $\left(500-950^{\circ} \mathrm{C}\right)$. Maximum devitrification occurs at $600^{\circ} \mathrm{C}$.

Although the waste glasses are complex, the growth kinetics follow the expected trends based on theoretical models of simple glasses, e.g. smooth fractional ingrowth curves are achieved as a function of aging. Comparison of the TTT curves demonstrates that iron in the waste composition promotes spinel formation as suggested by welch et al [12]. This is especially true for higher temperatures at shorter times, e.g. in the range of melter idling conditions. The liquidus temperature (defined as the highest temperature of appearance of spinel) correlates with increasing $\mathrm{Fe}_{2} \mathrm{O}_{3} / \mathrm{SiO}_{2}$ content of the glass in mole percent.

The formation of spinel has little or no effect on leachability, while the formation of acmite produces a small but noticeable increase in the rate of dissolution of the matrix glass. Quenched SRL-13l glasses are less durable than the current reference glass, SRL-165, as reported previously $[13,14]$. The two additional alkali silicate devitrification products in SRL-131 are leachable phases which cause poorer overall durability. Devitrification only increases leachability of a given glass composition by $2-3 x$. Moreover, devitrification does not produce any significant effect on the leachability of radioactive SRL-165 waste glasses devitirfied at higher than normal crystallizations [15]. Thus, leach rates from SRL glass subjected to accident conditions, or moderate temperatures for long time periods will be similar to those of unaged glass of the same composition.

The effects of devitrification on the durabjlity of the SRL waste glasses demonstrates that devitrification has less of an effect than compositional changes. Examination of the glass surface at the glass-leached layer reaction zone of quenched glasses indicates that glass dissolution is non-uniform. The reaction zone in devitrified samples is similar. It is impossible to determine whether accelerated attach is the result of grain boundary dissolution or localized surface damage at the glass/crystal boundary during sample preparation. Further examination of the leached layer at the gel-solution interface indicates that formation of the leached layer shields the grain boundaries from further dissolution. Leach rate enhancement from selective grain boundary attack in devitrified glass does not occur.

\section{ACKNOWLEDGMENT}

The information contained in this article was developed during the course of work under Contract No. DE-AC09-76SR00001 with the U.S. Department of Energy. 
1. B. F. Zhu, D. E. Clark, L. L. Hench, and G. G. Wicks, "Leaching Behavior of Nuclear Waste Glass Heterogeneities" submitted J. Non-Crystall ine Solids.

2. A. E. Ringwood and P. E. Willis, Nature, 311, pp 735-737 (1984).

3. C. M. Jantzen, D. F. Bickford, and D. G. Karraker, Advances in Ceramics, 8, Am. Ceram. Soc. Columbus, OH, pp 30-38, 1984.

4. D. F. Bickford, and C. M. Jantzen, Sci. Basis for NuCl. Waste Mgt. VII, G. L. McVay (ed), El sevier PubT, NY, pp 557-566, 1984.

5. J. A. Stone, S. T. Goforth Jr. and P. K, Smith, "Preliminary Evaluation of Alternative Forms for Immobilization of Savannah River Plant HighLevel Waste," DP-1545, E. I. Du Pont Savannah River Laboratory, December 1979.

6. C. M. Jantzen and D. G. Karraker, "Quantitative X-ray Diffraction and Magnetic Susceptibility for Devitrification Studies, in prep, Am. Ceram. Soc.

7. D. M. Strachan, B. 0. Barnes, and R. P. Turcotte, Sci. Basis for Nucl. Waste ilgt., III, J. G. Moore (ed), Plenum Press, New York, 347-354, $\overline{1981}$

8. P. B. Macedo and A. Barkatt, Battelle Pacific Northwest Laboratory, Richland, WA, PNL-5157, 1.1-1.63, August 1984.

9. A. B. Harker, Battelle Pacific Northwest Laboratory, Richland, WA, PNL-5157, 2.1-2.37, August 1984.

10. J. F. Flintoff and A. B. Harker, "Detailed Processes of Surface Layer Formation in Borosilicate Waste Glass Dissolution" this volume.

11. C. M. Jantzen, "Surface Layer Formation During Glass Leaching: Role of Bond Energetics and Zeta Potential" Abs. for 87th Annual Meeting of American Ceramic Society, April 1985.

12. J. M. Welch, R. L. Miller, and J. E. Flinn, Advances in Ceramics, $\underline{8}$, $611-618,1984$.

13. M. J. Plodinec, C. M. Jantzen, and G. G. Wicks, Advances in Ceramics, $\underline{8}, 385-393,1984$.

14. C. M. Jantzen and M. J. Plodinec, J. Non-Crystalline Solids, 67, 207-223, 1984.

15. N. E. Bibler, Glastechn. Ber. 56K, 736-742, 1983. 


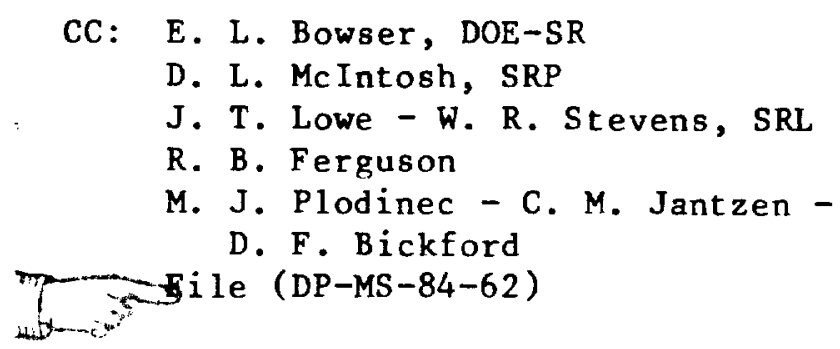

November 16,1984

TO DISTRIBUTION

Attached is a copy of the following:

DP-MS-84-62, "LEACHING OF DEVITRIFIED GLASS CONTAINING SIMULATED SRP NUCLEAR WASTE", by C. M. Jantzen and D. F. Bickford.

A paper proposed for presentation at the Materials Research Society Meeting to be held November 26-30, 1984 in Boston, Mass. and for publication in the Proceedings of the Meeting.

If any technical clarification is needed please call C. J. Banick.

If there are comments about its release, notify the Records Management Office within 14 days (Ext. 2606).

For any technical clarification, we suggest you call:

R. B. Ferguson, Research Manager Waste Solidification Technology Division Savannah River Laboratory 